\title{
Therapeutic laser with or without andiroba oil in treating cutaneous wounds by second intention in Wistar rats
}

\author{
Laser terapêutico associado ou não ao óleo de andiroba no tratamento \\ de feridas cutâneas por segunda intenção em ratos Wistar \\ Romulo Silva de Oliveira ${ }^{1} \oplus$, Mayara Marques Pereira Fernandes ${ }^{1} \oplus$, \\ Millena do Nascimento Mesquita ${ }^{1}{ }^{\circ}$, Ana Caroline Lima da $\operatorname{Cruz}^{1}{ }^{\circledR}$, \\ Charles Pelizzari ${ }^{\circledR}$, Eduardo Cavalcante das Neves ${ }^{\circledR} \odot$, Rui Carlos Peruquetti ${ }^{\circledR} \odot$, \\ Marina Maurente Berón ${ }^{3} \odot$, Aline de Marco Viott ${ }^{4} \odot$, Soraia Figueiredo de Souza ${ }^{1^{*}}([)$
}

\begin{abstract}
This study's objective was to evaluate the efficacy of treating cutaneous wounds in Wistar rats using a therapeutic laser alone or in combination with topical application of andiroba oil. Twenty-four Wistar rats were distributed into three groups (T4, T7, and T14) of eight animals. To prepare the wounds, a total of four skin fragments per animal were removed using an 8-mm cutaneous biopsy punch. Each animal was inflicted with four surgical wounds, and each wound was subjected to one treatment. The treatments were as follows: saline solution (control, Cn); laser therapy (L), using a 660-nm laser wavelength and $10-\mathrm{J} / \mathrm{cm}^{2}$ energy density; fresh andiroba oil (An); laser therapy followed by topical andiroba oil administration (LAn). All treatments in all animals were conducted for 4- (T4), 7- (T7), and 14- (T14) day periods. Edema and purulent secretion were observed in three animals in the An group, and the appearance of an exuberant crust was also observed in one animal from the same group. The LAn group presented the worst wound healing rate and contraction velocity $(p<0.05)$. Microscopically, there was no difference between groups regarding the presence of inflammation, necrosis, formation of granulation tissue, fibroplasia, and the presence of types 1 and 3 collagen at different treatment times. It was concluded that laser treatment of cutaneous wounds in conjunction with andiroba oil application did not present benefits in reference to the $0.9 \% \mathrm{NaCl}$.
\end{abstract}

KEYWORDS: Andiroba; Healing; Phytotherapy; InGaAlP.

RESUMO: O objetivo deste estudo foi avaliar a eficácia do tratamento de feridas cutâneas em ratos Wistar utilizando o laser terapêutico em associação ou não com o óleo de andiroba. Vinte e quatro ratos foram avaliados em três tempos de tratamento (T4, T7 e T17), sendo oito animais em cada tempo. Para a realização das feridas cirúrgicas, quatro fragmentos de pele foram removidos com punch de biopsia de 8 milímetros. Cada animal recebeu quatro feridas e cada ferida foi tratada com um tratamento: solução salina (controle, Cn); laserterapia (L), usando um laser com comprimento de onda de $660 \mathrm{~nm}$ e $10 \mathrm{~J} / \mathrm{cm}^{2} \mathrm{de}$ densidade de energia; óleo de andiroba in natura (An); e laserterapia seguida pela administratação tópica de óleo de andiroba (LAn). Todos os tratamentos foram realizados e avaliados nos dias quatro (T4), sete (T7) e 14 (T14) de pós operatório. Foram observados edema e secreção purulenta em três animais do grupo An, e a presença de crosta exuberante também foi obervada em um animais do mesmo grupo. O grupo LAn apresentou a pior cicatraização e velocidade de contração da ferida $(p<0,05)$. Não houve diferença entre os grupos à avaliação microscópica da presença de inflamação, necrose, formação de tecido de granulaçáo, fibroplasia e presença de colágeno tipo 1 e tipo 3 nos diferentes tempos de tratamento. Foi possível concluir que o tratamento com laseterapia em associação ao óleo de andiroba não apresentou benefícios em relação a utilização da solução de cloreto de sódio a $0,9 \%$.

PALAVRAS CHAVE: Andiroba; Cicatrização; Fitoterapia; InGaAlP.

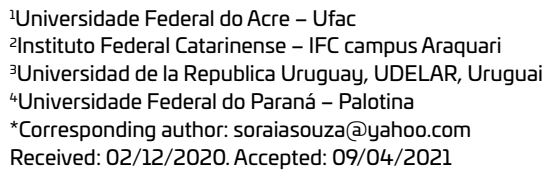




\section{INTRODUCTION}

Healing is a systemic process, and its efficiency is linked to an organism's conditions. Several mechanisms acting jointly are needed for healing to occur (CAMPOS, BORGES-BRANCO; GROTH, 2007). Healing is usually classified into three stages: inflammation, proliferation, and maturation (BAUM; ARPEY, 2006).

The main objective of wound management is to allow the skin to heal as soon as possible and decreasing pain (DEVRIENDT; DE ROOSTER, 2017).

Non-traditional therapeutic modalities, such as phytotherapy, have gained popularity in medical treatment, reflected by an increase in the number of studies and natural products to augment healing (OLIVEIRA et al., 2010). In Brazil, andiroba, also known as crabwood (Carapa guianensis), is used topically for wounds and bruises as a healing agent and is also used for several other skin diseases. Andiroba's main effects include disinfection, healing, analgesia, and anti-inflammation (GILBERT, 2006; NAYAK et al., 2011).

Andiroba seed oil is composed mainly of triglycerides and fatty acids; however, it also contains limonoids and phytochemicals found in the Meliaceae family (SILVA, 2018).

Low-intensity laser therapy, originally described by Theodore Maiman in the form of a ruby laser, is another therapy used to promote tissue regeneration in addition to reducing inflammation and relieving pain (MAIMAN, 1960).

There is a wide variation in the recommended energy densities for stimulating healing, usually ranging from 1 to $10 \mathrm{~J} / \mathrm{cm}^{2}$; however, values ranging from 0.5 to $32 \mathrm{~J} / \mathrm{cm}^{2}$ have also been suggested (LOW; REED, 2001).

To date, no studies have been conducted on the combination of laser therapy with andiroba oil in treating cutaneous wounds. This study's objective was to evaluate the efficacy of treating cutaneous wounds by second intention using therapeutic laser treatment with or without topical andiroba oil application in Wistar rats.

\section{MATERIAL AND METHODS}

This study was approved by the Ethics Committee on Animal Use of the Federal University of Acre, registered under protocol 50/2016. Twenty-four male Wistar rats (Rattus norvegicus) weighing approximately $350 \mathrm{~g}$ and at approximately 100 days of age were used. The rats were kept in polypropylene boxes in an air-conditioned room at an approximate temperature of $24^{\circ} \mathrm{C}$ and relative humidity of $40-60 \%$, acclimatized for $7 \mathrm{~d}$, and fed a commercial rodent formulation and water ad libitum. Each rat was inflicted with four surgical wounds, and each wound received a different treatment among the four available treatments. Eight individuals were histologically evaluated thrice (4, 7, and 14 days after treatment), totaling 24 rats.

To inflict surgical wounds, trichotomy was performed in the dorsal thoracic-abdominal region, and the rats were anesthetized using a combination of ketamine $(25 \mathrm{mg} / \mathrm{kg})$ and tramadol $(10 \mathrm{mg} / \mathrm{kg})$, administered intramuscularly, and then maintained through inhalation of isoflurane vaporized with oxygen at $100 \%$. Antisepsis was performed using $70 \%$ ethyl alcohol and $2 \%$ chlorhexidine digluconate.

Four skin fragments were removed per animal for wound preparation using an 8-mm cutaneous biopsy punch. The wounds were cleaned daily with $0.9 \%$ sodium chloride solution prior to therapeutic application. Postoperative analgesia was administered subcutaneously using tramadol hydrochloride $(10 \mathrm{mg} / \mathrm{kg})$ every $12 \mathrm{~h}$ for three days.

The wounds received the following treatments: saline solution (control, $\mathrm{Cn}$ ); laser therapy (L); fresh andiroba oil only (An); and laser therapy followed by topical administration of andiroba oil (LAn). The four treatment groups were tested in all individuals in the study to minimize possible individual variations. The three treatment times were determined by the date of euthanasia and referred to as T4 $(4 \mathrm{~d}$ of treatment), T7 (7 d of treatment), and T14 (14 d of treatment). All treatments started $2 \mathrm{~h}$ after the surgical procedure and were repeated daily for up to $14 \mathrm{~d}$.

Andiroba seed oil was obtained from the municipal market of Rio Branco, State of Acre (9'58'35.5”S, 67\%48'26.9”W), and extracted using artisanal methods (FERRAZ; CAMARGO; SAMPAIO, 2003).

The therapeutic laser used was from a Photon Vet ${ }^{\circledR}(\mathrm{DMC}$ Equipamentos, São Carlos, Brazil), with a wavelength of 660 $\mathrm{nm}$, characterized by an aluminum gallium indium phosphate laser (InGaAlP). The energy density used was $10 \mathrm{~J} / \mathrm{cm}^{2}$, a power of $30 \mathrm{~mW}$ in continuous punctual mode, and an application time of $9 \mathrm{~s}$.

For macroscopic evaluation, the animals were examined for the presence of edema, crusts, secretions, and measurement of scar retraction of wounds daily using a digital caliper until total healing.

The healing rate was calculated according to the formula: $T C=\frac{\frac{A i-A f}{A A}}{D \text { Dys }}$, where $T C$ is the healing rate $\mathrm{in}^{2} / \mathrm{day}, A i$ the initial area of the lesion in $\mathrm{mm}^{2}$, and $A f$ is the final area of the lesion, indicating healing per day. Another index used was the contraction of the lesion represented by the formula $C L=\frac{A i-A d e s p}{A i}$, where $C L$ is the contraction of the lesion in $\mathrm{mm}^{2}, A i$ is the initial area of the lesion in $\mathrm{mm}^{2}$, and Adesp is the area of the lesion in $\mathrm{mm}^{2}$ on a specific day (BUZZI; FREITAS; WINTER, 2016).

For histopathological evaluation, eight animals were euthanized on days 4,7 , and 14 of the study $(n=24)$ in a euthanasia chamber. Afterward, intramuscular xylazine hydrochloride at a dose of $30 \mathrm{mg} / \mathrm{kg}$ was administered under isoflurane vaporization in oxygen at $100 \%$.

For the collection of cutaneous fragments, four fragments with a minimum margin of $1 \mathrm{~cm}$ between each wound and depth up to the muscular fascia were excised, identified, fixed in $10 \%$ buffered formaldehyde solution, and subsequently 
processed in standard histopathologic routine and divided into paraffin blocks.

The samples were sent to the Laboratory of Veterinary Pathology at the Federal University of Parana, Palotina Sector, where they were processed using the routine paraffin inclusion technique (TOLOSA, 2003). The paraffinized tissue was processed and stained with hematoxylin and eosin and picrosirius red. The stained slides were blindly read by three different individuals using optical microscopy (Olympus CX41; Olympus Corporation, Tokyo, Japan), and interpretation was conducted by scoring the degree of inflammation, necrosis, fibroplasia, and granulation tissue ( 0 , absent; 1 , mild; 2 , moderate; and 3, marked).

The slides stained using the picrosirius red technique were blind-read using conventional optical microscopy by three different individuals, with the aid of two polarizing filters that promoted birefringence in the stained collagen. Under polarized light, type I collagen is identified as thick, birefringent fibers in a yellow or red color, and type III collagen appears in thin, low-refringent bundles of greenish color that receive scores according to the intensity presented in the slide (1, mild; 2 , moderate; and 3 , marked).

The images were captured using a Leica DM 1000 microscope coupled with a Leica DFC295 camera (Leica Camera, Wetzlar, Germany). The areas of the lesions did not present a normal distribution (Kolmogorov-Smirnov test; $D=0.08$; $p<0.0001 ; n=896$ ); thus, non-parametric tests were used for comparisons between groups or between treatments. Analyses were performed using Bioestat version 5 (AYRES; AYRES JÚNIOR; AYRES, 2007; ZAR, 2010).

\section{RESULTS}

Edema was present in the An group in three rats from the 2 nd to the 12th postoperative day. In group L, edema occurred in one rat on days 6, 7, and 8, and in the LAn group, one rat presented edema on the 2 nd postoperative day. The presence of purulent exudate was observed from the 2 nd to the 8 th postoperative day in three rats in group An. In the same group, crust formation was observed on the 3 rd day of treatment in an individual (Figure 1). Only one rat showed reepithelialization of the four wounds during the period evaluated.

The injury contraction index and healing rate are depicted in Figure 2.

There were no statistical differences in inflammation, necrosis, fibroplasia, and granulation tissue among the groups at times 4,7 , and 14 post-operation (Table 1 ).

The amount of type 1 collagen in the wounds at different times is shown in Figure 3.

Type 3 collagen was found in two T4 wounds, one in the $\mathrm{Cn}$ group and the other in the $\mathrm{L}$ group. On the 7 th day post-operation, collagen was found in three wounds in the Cn group.

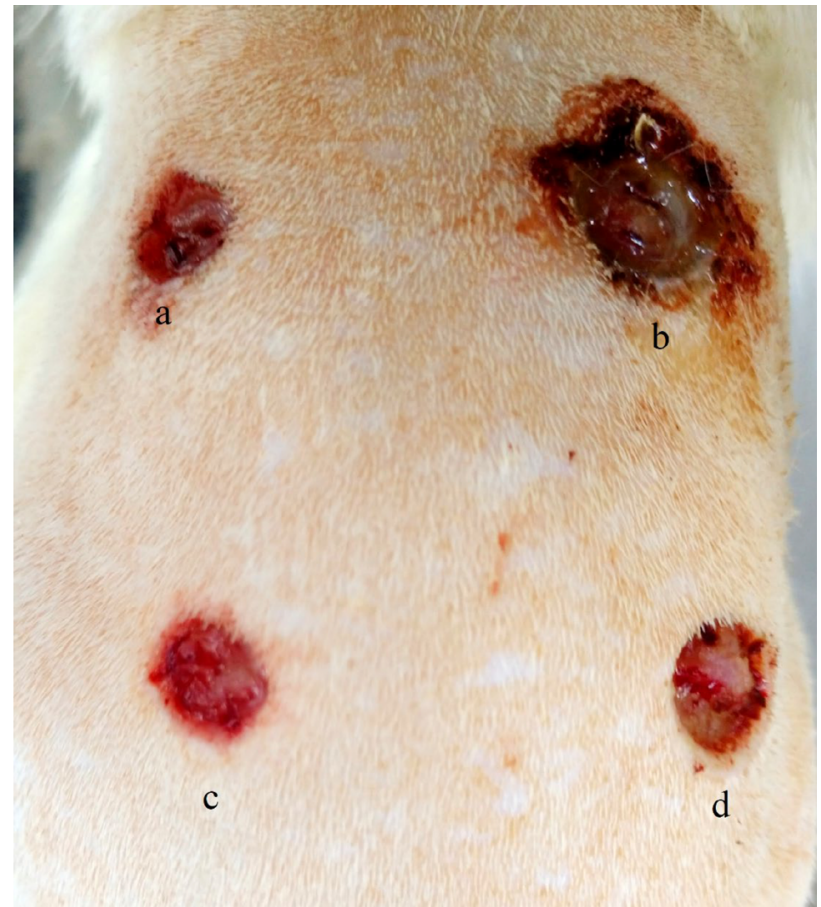

Figure 1. Cutaneous wounds in the thoracic-lumbar region induced surgically in Wistar rats and treated with physiological solution (a), andiroba oil (b), laser therapy (c), and laser therapy combined with andiroba seed oil application (d). In (b), crust formation is noted.

\section{DISCUSSION}

The presence of crusts in the wounds of animals treated with andiroba oil was consistent with the findings of Brito and colleagues (BRITO et al., 2001), who evaluated the healing capacity of andiroba oil applied in natura in Wistar rat wounds and observed that those treated with andiroba oil presented a fibrin-leukocyte crust of greater size and thickness with the presence of abundant exudate in the first $3 \mathrm{~d}$ and edema when compared with the control of $0.9 \% \mathrm{NaCl}$. Other studies using phytotherapy in treating wounds, such as those by (SANTOS et al., 2006; KOBAYASHI et al., 2015), observed a crust formation tendency in Wistar rats.

Among the several effects of laser therapy, one particularly important effect is edema reduction (LOW; REED, 2001). In the LAn group, one animal presented edema only during the 2 nd day post-operation day, suggesting that laser therapy may help prevent edema when used in combination with andiroba oil in wound healing by second intention.

Regarding the healing rate and the injury contraction index (Figure 2), the use of andiroba oil alone or combined with laser therapy delayed the reduction of the wound area at 7 and $14 \mathrm{~d}$ of evolution compared with the Cn group $(p<0.005)$. At T4, andiroba oil's ability to reduce wound contraction was similar to the $\mathrm{Cn}$ group and had an inferior healing rate than the other groups. This result differs from another study in which the authors found lower measurements in the areas 
A

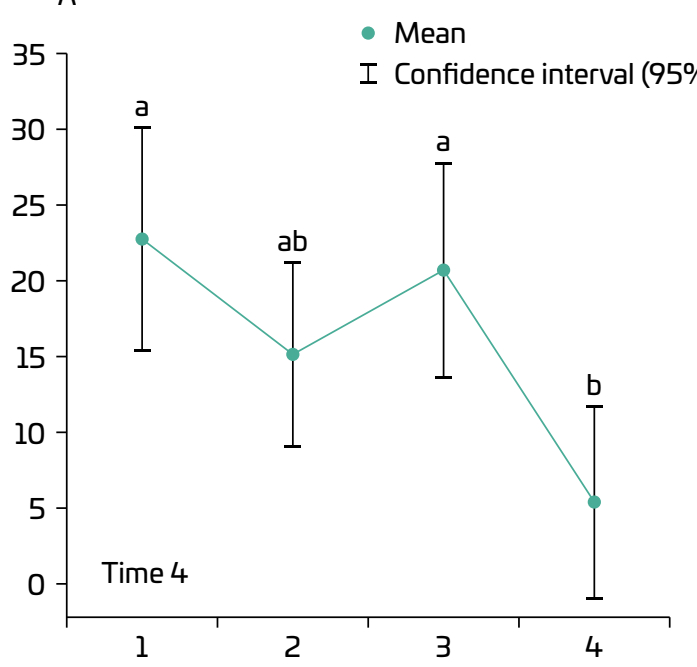

B

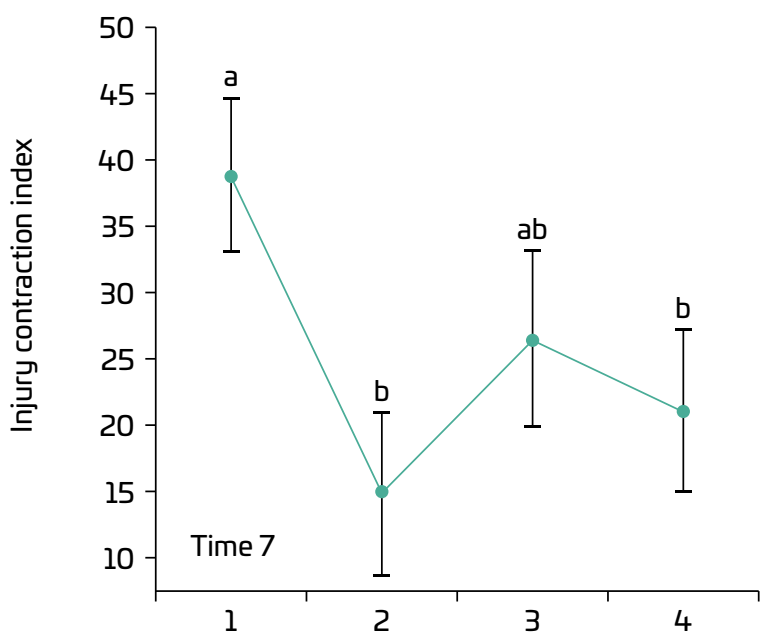

C

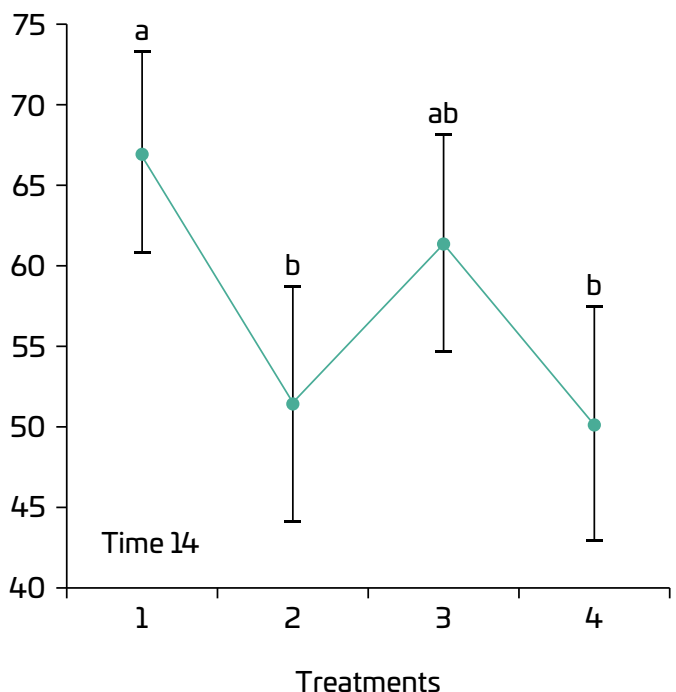

D

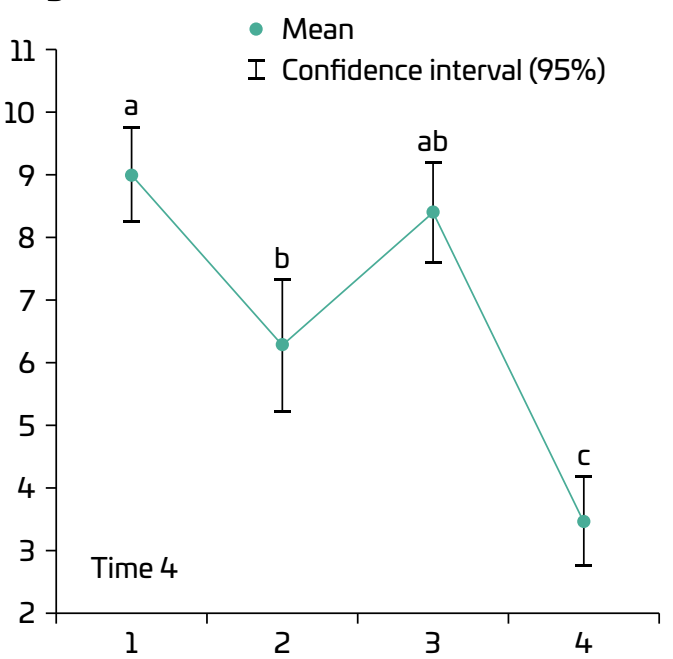

$\mathrm{E}$

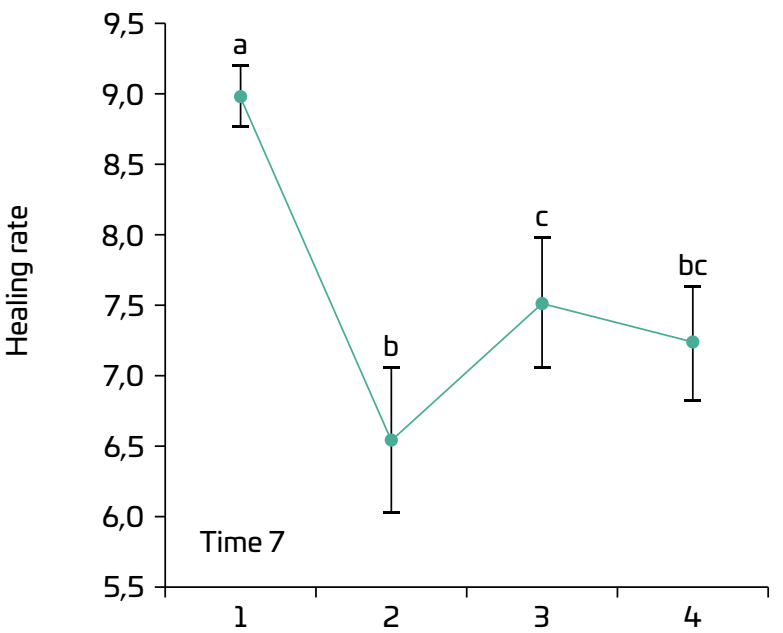

$\mathrm{F}$

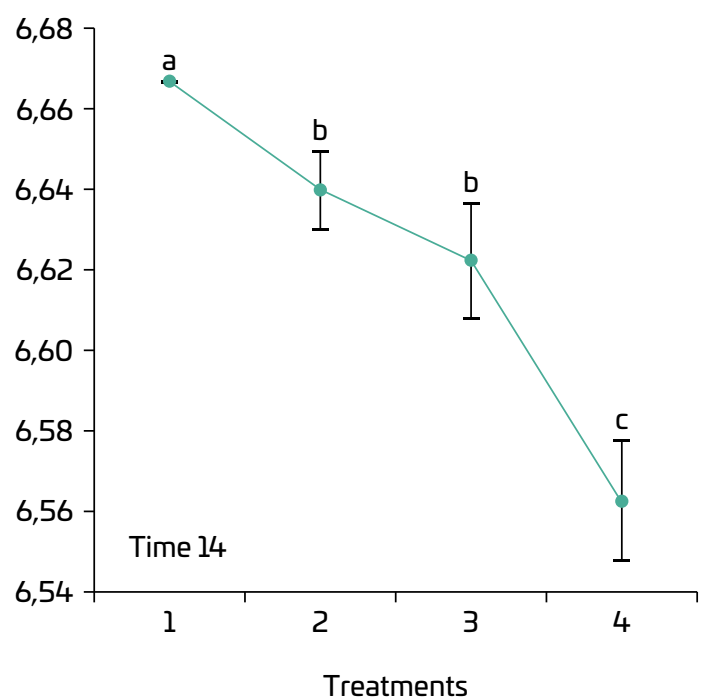

Figure 2. The lesion contraction rates are shown in A, B, and C. The healing rate of cutaneous wounds in Wistar rats treated with physiological solution (1), andiroba oil (2), laser therapy (3), and laser therapy combined with andiroba seed oil application (4) on days 4, 7, and 14 are shown in D, E, and F. Different letters (a, b, and c) indicate statistical differences between groups. 
Table 1. Degrees of inflammation, necrosis, granulation tissue formation, and fibroplasia of Wistar rat epithelium with healing by second intention treated using a physiological solution, andiroba oil, laser therapy, and laser therapy combined with andiroba seed oil application with 4,7 , and 14 days of evolution.

\begin{tabular}{|c|c|c|c|c|c|c|c|c|c|c|c|c|c|c|c|c|}
\hline \multirow{2}{*}{ Lesion degree } & \multicolumn{4}{|c|}{ Inflamation $\left(n^{1}\right)$} & \multicolumn{4}{|c|}{ Necrosis $(n)$} & \multicolumn{4}{|c|}{ Granulation $(n)$} & \multicolumn{4}{|c|}{ Fibroplasia $(n)$} \\
\hline & 0 & I & II & III & 0 & 1 & II & III & 0 & 1 & II & III & 0 & I & II & III \\
\hline \multicolumn{17}{|l|}{ Time 4} \\
\hline Control (Cn) & 0 & 2 & 5 & 1 & 0 & 4 & 3 & 1 & 0 & 6 & 1 & 1 & 8 & 0 & 0 & 0 \\
\hline Andiroba (An) & 0 & 5 & 3 & 0 & 0 & 4 & 4 & 0 & 0 & 5 & 3 & 0 & 8 & 0 & 0 & 0 \\
\hline Laser (L) & 0 & 2 & 5 & 1 & 0 & 1 & 6 & 1 & 0 & 7 & 1 & 0 & 8 & 0 & 0 & 0 \\
\hline Laser + Andiroba (Lan) & 1 & 7 & 0 & 0 & 1 & 2 & 2 & 3 & 1 & 5 & 1 & 1 & 7 & 1 & 0 & 0 \\
\hline \multicolumn{17}{|l|}{ Time 7} \\
\hline Control (Cn) & 3 & 5 & 0 & 0 & 3 & 4 & 1 & 0 & 3 & 4 & 1 & 0 & 7 & 1 & 0 & 0 \\
\hline Andiroba (An) & 0 & 5 & 3 & 0 & 1 & 3 & 4 & 0 & 0 & 2 & 6 & 0 & 7 & 1 & 0 & 0 \\
\hline Laser (L) & 0 & 6 & 1 & 1 & 0 & 1 & 5 & 2 & 0 & 2 & 5 & 1 & 8 & 0 & 0 & 0 \\
\hline Laser + Andiroba (Lan) & 0 & 6 & 2 & 0 & 0 & 7 & 1 & 0 & 0 & 3 & 5 & 0 & 8 & 0 & 0 & 0 \\
\hline \multicolumn{17}{|l|}{ Time 14} \\
\hline Control (Cn) & 8 & 0 & 0 & 0 & 8 & 0 & 0 & 0 & 8 & 0 & 0 & 0 & 0 & 8 & 0 & 0 \\
\hline Andiroba (An) & 8 & 0 & 0 & 0 & 8 & 0 & 0 & 0 & 8 & 0 & 0 & 0 & 0 & 8 & 0 & 0 \\
\hline Laser (L) & 8 & 0 & 0 & 0 & 8 & 0 & 0 & 0 & 8 & 0 & 0 & 0 & 0 & 8 & 0 & 0 \\
\hline Laser + Andiroba (Lan) & 8 & 0 & 0 & 0 & 8 & 0 & 0 & 0 & 8 & 0 & 0 & 0 & 0 & 8 & 0 & 0 \\
\hline
\end{tabular}

${ }^{1} n$ : number of animals in each group that presented the lesion and its degree.

O, absent; I, mild; II moderate; and III, marked.

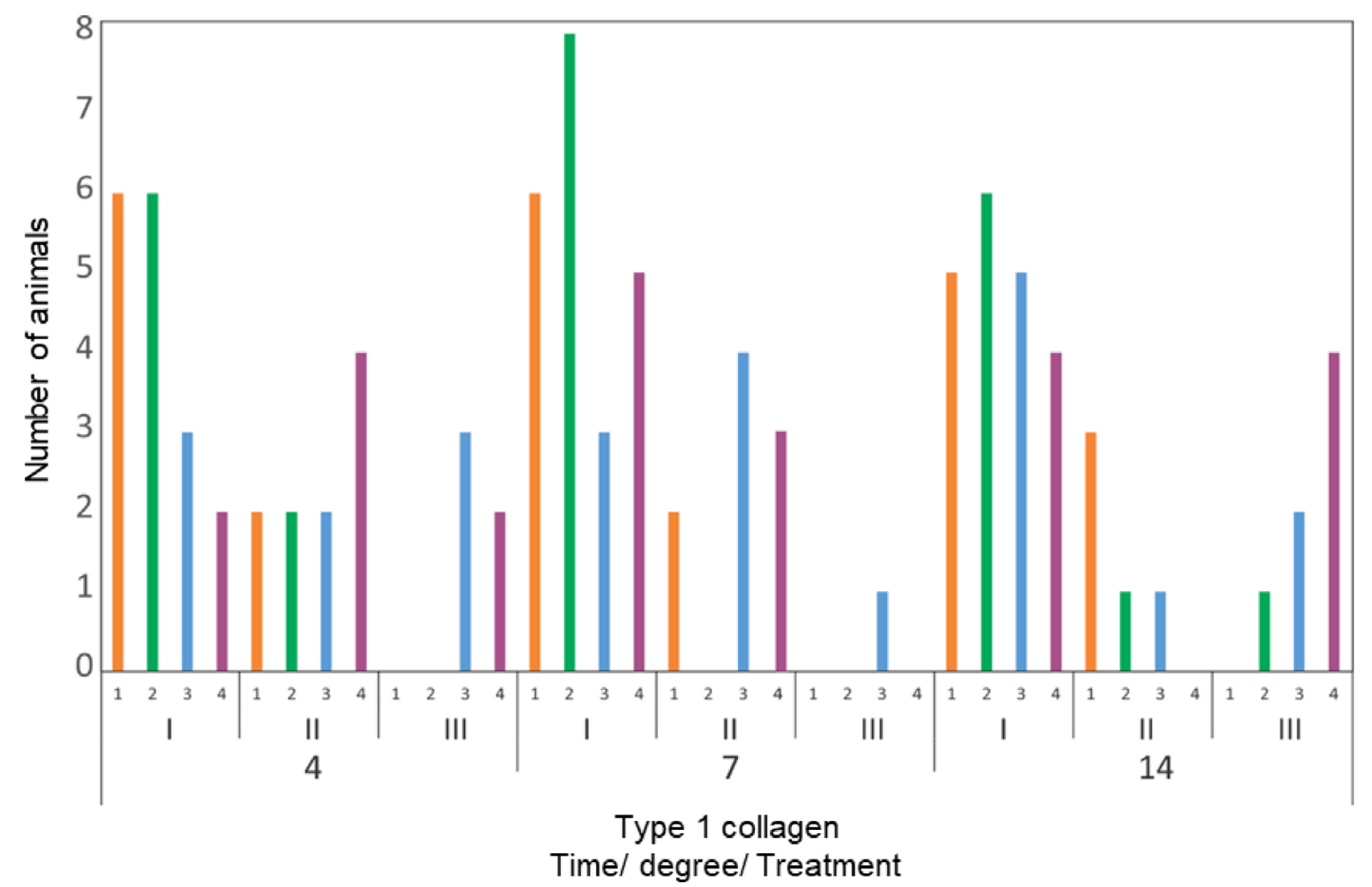

Figure 3. Intensity of type l collagen in Wistar rat cutaneous wounds treated using a physiological solution, andiroba oil, laser therapy, and laser therapy combined with andiroba seed oil application, classified as I, mild; II, moderate; or III, marked. The treatment groups are represented by colors in the following sequence: orange, control (Cn); green, andiroba (An); blue, laser (L); and purple, laser + andiroba (Lan) at days 4, 7, and 14. 
of cutaneous lesions of diabetic rats treated with andiroba on days 7,14 , and 21 compared with the control group (SOUZA et al., 2017). Andiroba concentrations of 20 and $50 \%$ were tested in Wistar rat wounds, and no difference was observed in the reduction of the treated lesion area in relation to the control group, suggesting that high concentrations of the active ingredient may be harmful, which was corroborated in the present study (FERNANDES et al., 2014).

The laser energy density of $10 \mathrm{~J} / \mathrm{cm}^{2}$ used to treat Wistar rat wounds did not accelerate healing rate and wound contraction time compared with the other groups evaluated. To the best of our knowledge, this is the first report on the use of a $10-\mathrm{J} / \mathrm{cm}^{2}$ InGAlP laser energy density for the treatment of Wister rat cutaneous wounds. An InGAlP laser has been used at energy densities of 3 and $6 \mathrm{~J} / \mathrm{cm}^{2}$ to treat open wounds in Wistar rats, and a reduction in healing time $(p<0.05)$ on the 10th day post-operation using the $3 \mathrm{~J} / \mathrm{cm}^{2}$ energy density was macroscopically observed, which may indicate that lower amounts of energy have a better effect (TACON et al., 2011 ). In a study using $0.5,1.5$, and $4 \mathrm{~J} / \mathrm{cm}^{2}$ energy densities, no statistical differences in wound closure were observed (WALKER et al., 2000).

The combination of phytotherapy and laser therapy with the dosimetry used did not show beneficial effects on the isolated treatment; instead, it exhibited the worst healing rates in several cases.

Although the antibacterial function of andiroba oil has been documented, the An group had the highest frequency of purulent secretions, corroborated by the findings of Nayak and colleagues (2011), who tested the sensitivity of several bacterial colonies to an ethanolic andiroba extract and found that $P$. aeruginosa, $K$. pneumoniae, E. faecalis, E. coli, $S$. aureus, and methicillin-resistant $S$. aureus were not sensitive to the extract, which could explain the presence of purulent secretion.

Although the use of andiroba oil in its pure form resulted in macroscopically inferior results, this was not replicated in the microscopic assessments, where there was no difference between the groups in any of the parameters evaluated (inflammation, necrosis, formation of granulation tissue, fibroplasia, and evaluation of type 1 and 3 collagens) at the three treatment times (4, 7 , and $14 \mathrm{~d}$ post-operation).

The presence of inflammation, necrosis, and granulation tissue was verified at days 4 and 7 in all groups being absent 14 days post-operation, suggesting that the scarring process occurred similarly in all treatments. Fibroplasia was mild in an individual of the LAn group at day 4 , as in one individual each in the $\mathrm{Cn}$ and An groups 7 days post-operation and in all rats at day 14 , which may indicate that a longer observation time could have presented higher fibroplasia degrees. In a similar study where andiroba was used at concentrations of 20 and $50 \%$ for treating cutaneous wounds in Wistar rats, there was no difference in the histological parameters between the groups on days 4, 7, 14, and 21 of treatment (FERNANDES et al., 2014).

The presence of type I collagen at $14 \mathrm{~d}$ post-operation was not verified in the Cn group rats but was verified in one, two, and four rats in groups An, L, and LAn, respectively. Although they were no statistically significant differences, this result may suggest that the treatments were beneficial with regards to type 1 collagen; however, further research is required to confirm this.

The scarcity of type 3 collagen in all groups can be attributed to the presence of mild fibroplasia at T14, suggesting that further studies with longer evaluation times must be performed to elucidate the behavior of type 3 collagen in Wistar rat cutaneous wounds. However, collagenization was perceived on the 7th day post-operation in healing colon surgery in rats (SILVA et al., 2015).

Cutaneous wound treatment in Wistar rats using andiroba, alone or in combination with a therapeutic laser, was not beneficial with regards to wound healing time and the microscopical aspects evaluated in relation to using a $0.9 \% \mathrm{NaCl}$.

\section{REFERENCES}

AYRES, M.; AYRES JÚNIOR, M.; AYRES, D.L. et al. BioEstat 5.0: aplicações estatísticas nas áreas das ciências biológicas e médicas. 1. ed. Pará: Sociedade Civil Mamirauá, 2007. 364p.

BAUM, C. L.;ARPEY, C. J. Normal Cutaneous Wound Healing: Clinical Correlation with Cellular and Molecular Events. Dermatologic Surgery, v. 31, n. 6, p. 674-686, 2006.

BRITO, N. M. B.; SILVA, P. R. F.; SILVA, G. C. F.; et al. Avaliação macroscópica de feridas cutâneas abertas, em ratos, tratadas com óleo de andiroba. Revista Paraense de Medicina, v. 15, n. 2, p. 17-22, 2001.
BUZZI, M.; FREITAS, F.; WINTER, M. B. Cicatrização de úlceras por pressão com extrato Plenusdermax ${ }^{\circledR}$ de Calendula officinalis L. Revista Brasileira de Enfermagem, v. 69, n. 2, p. 250-257, 2016.

CAMPOS, A. C. L.; BORGES-BRANCO, A.; GROTH, A. K. Cicatrização de feridas. Arquivo Brasileiro de Cirurgia Digestiva ABCD, v. 20, ก. 1, p. 51-58, 2007.

DEVRIENDT, N.; DE ROOSTER, H. Initial Management of Traumatic Wounds. Veterinary Clinics of North America: Small Animal Practice, v. 47, n. 6, p. 1123-1134, 2017. 
FARIVAR, S.; MALEKSHAHABI, T.; SHIARI, R. Biological Effects of Low Level Laser Therapy. Lasers in Medical Science, v. 5, n. 2, p. 58-62, 2014.

FERNANDES, C. P. M.; LIMA, C. S.; LOPES, T. V. et al. Utilização do óleo de andiroba (Carapa guianensis) em feridas cutâneas de ratos Wistar Revista Brasileira de Higiene e Sanidade Animal, v. 8, n. 3, p. 17-159, 2014.

FERRAZ, I. D. K.; CAMARGO, J. L. C.; SAMPAIO, P. T. B. Carapa guianensis Aubl. Carapa procera D. C. Manual de sementes da Amazônia. l. ed. Manaus: INPA, 2003.

GILBERT, B. Produtos naturais industrializáveis da Amazônia. Revista Fitos, v. 2, n. 3, p. 30-38, 2006.

KOBAYASHI, Y. T. S.; ALMEIDA, V. T.; BANDEIRA, T. et al. Avaliação fitoquímica e potencial cicatrizante do extrato etanólico dos frutos de Jucá (Libidibia ferrea) em ratos Wistar. Brazilian Journal of Veterinary Research andAnimal Science, v. 52, n. 1, p. 34-40, 2015.

LOW, J.; REED, A. Eletroterapia explicada: princípios e prática. 3. ed. São Paulo: Manole, 2001. 472p.

MAIMAN, T.H. Stimulated optical radiation in Ruby. Nature, v. 187 p. 187-193, 1960.

NAYAK, B. S.; KANHAI, J.; MILNE, D. M. et al. Experimental Evaluation of Ethanolic Extract of Carapa guianensis L. Leaf for Its Wound Healing Activity Using Three Wound Models. Evidence-Based Complementary and Alternative Medicine, 2011.

OLIVEIRA, A. F.; BATISTA, J. S.; PAIVA, E. S. et al. Avaliação da atividade cicatrizante do jucá (Caesalpinia ferrea Mart. ex Tul. var. ferrea) em lesões cutâneas de caprinos. Revista Brasileira de Plantas Medicinais, v. 12, n. 3, p. 302-310, 2010.

SANTOS, M. F. S.; CZECZKO, N. G.; NASSIF, P. A. N. et al. Avaliação do uso do extrato bruto de Jatropha gossypiifolia L. na cicatrização de feridas cutâneas em ratos. Acta Cirurgica Brasileira, v. 2l, n. 3, p. 2-7, 2006.

SILVA, C. E. S.; SANTOS, O. J.; RIBAS-FILHO, J. M. et al. Effect of Carapa guianensis Aublet (Andiroba) and Orbignya phalerata (Babassu) in colonic healing in rats. Revista do Colégio Brasileiro de Cirurgiões, v. 42, n. 6, p. 399-406, 2015.

SILVA, L. R. Propriedades físico-químicas e perfil dos ácidos graxos do óleo da andiroba. Nativa, v. 6, n. 2, p. 147-152, 2018.

SOUZA, B.A.A.; BRAGA, L. A.; LOPES, L. R. O. et al. Effects of Andiroba oil (Carapa guianensis) on wound healing in alloxan-diabetic rats. International Archives of Medicine, v. 10, n. 263, p. 1-7, 2017; 10.

TACON, K. C. B.; SANTOS; H. C. O.; PARENTE, L. M. L. et al. Healing activity of laser InGaAIP (660nm) in rats. Acta Cirurgica Brasileira, v. 26, п. 5, p. 373-378, 2011.

TOLOSA, E. M. C. Manual de Técnicas Para Histologia Normal e Patológica. 2. ed. Barueri: Manole, 2003.

WALKER, M. D.; RUMPF, S.; BAXTER, G. D. et al. Effect of lowintensity laser irradiation ( $660 \mathrm{~nm}$ ) on a radiation-impaired woundhealing model in murine skin. Lasers in Surgery and Medicine, $v$. 26, n. 1, p. 41-47, 2000.

ZAR, J. H. Biostatistical Analysis. 5. ed. New Jersey: Prentice Hall, 2010. 